\title{
FK 506 pre-treatment is associated with reduced levels of tumor necrosis factor and interleukin 6 following hepatic ischemia/reperfusion
}

\author{
Mahmoud F. Sakr ${ }^{a}$, Craig J. McClain ${ }^{\text {, }}$ Judith S. Gavaler ${ }^{b}$, Giorgio M. Zetti ${ }^{a}$, Thomas E. Starzl ${ }^{a}$ \\ and David H. Van Thiel ${ }^{\mathrm{a}}$
}

Departments of 'Surgery and 'Medicine. University of Pittsburgh School of Medicine. Pittsburgh, PA. United States of America and 'The Department of Medicine. University of Kentucky College of Medicine, Lexington, KY, United States of America

(Received 11 November 1991)

Using a rat model, the effect of pre-treatment with FK 506 on hepatic ischemia/reperfusion injury was investigated. All control animals died within $72 \mathrm{~h}$ of the ischemia/reperfusion injury. Pre-treatment of the animals with FK 506 $(0.3 \mathrm{mg} / \mathrm{kg}$ in $0.5 \mathrm{ml}$ saline $)$ administered intravenously improved survival. The most striking protection against fatal ischemia/reperfusion injury was achieved in rats that were given FK 5066 and $24 \mathrm{~h}$ prior to the induction of the hepatic ischemic insult (70\% and 80\% 10-day survival rates, respectively). The hepatoprotective effect of FK 506 was assessed further in a second experiment in which the serum levels of tumor necrosis factor (TNF) and interleukin 6 (IL-6) were measured. These results suggest that a $60-\mathrm{min}$ period of hepatic ischemia and subsequent reperfusion triggers the release of both TNF and IL-6, and that FK 506 pre-treatment ( $6 \mathrm{~h}$ before the ischemic episode) significantly inhibits the production and/or release of these two cytokines compared to untreated controls. These data provide additional information concerning the immunosuppressive and hepatoprotective activities of FK 506. Based upon these data, it is probable that FK 506 attenuates hepatic ischemia/reperfusion injury, at least in part, by reducing TNF and IL-6 levels.

Key words: Ischemia; Reperfusion; FK 506; Hepatotrophic factor; Cytokines; Liver injury; Immunosuppression

The success of organ transplantation. particularly liver transplantation (OLTx), as a treatment modality for endstage disease has created an increasing demand for donor organs that has outstripped the currently available donor supply. Compounding this problem is the observation that a number of donor livers either fail to function or function poorly in the immediate postoperative period $(1,2)$. As a result, considerable research effort has been devoted to identifying means for preventing or diminishing allograft injury resulting from organ harvesting, cold ischemia. reperfusion and rejection. FK 506, a potent immunosuppressive drug of the macrolide antibiotic class, has been shown to prevent or reverse both acute cellular and chronic allograft rejection in humans more reliably than has been possible heretofore (3). FK 506 has also been shown to possess hepatotrophic activity $(4,5)$. This latter effect is shared with cyclosporine A (CsA) $(6-11)$. Both drugs are T-cell specific immuno- suppressive agents that owe their immunosuppression activity to an inhibition of the synthesis and expression of interleukin 2 (IL-2) and possibly other cytokines $(12,13)$.

Tumor necrosis factor (TNF) and interleukin 6 (IL-6) are two cytokines recognized as critical eariy mediators of organ injury. One major source of TNF are 'activated' macrophages (14). The Kupffer cell mass within the liver is the largest fixed macrophage population of the body. Thus, the liver has a unique capacity for TNF production. Previous studies using diverse models of hepatotoxicity have suggested that TNF is a terminal mediator of liver injury (15-17). Indeed. TNF has been suggested to play a role in models such as galactosamine liver injury (15), lead-enhanced endotoxic liver injury (16) and Propionibacterium acnes-induced liver injury (17). Furthermore, agents with block TNF production (e.g., prostaglandins and dexamethasone) and/or anti-TNF 
antibodies have been shown to block or attenuate these models of liver injury $(15,17)$. TNF is known to be involved in many inflammatory processes, and it can be detected during renal (18) and cardiac (19) allograft rejection.

IL-6 is a glycoprotein which regulates growth and differentiation of both $B$ and $T$ lymphocytes, activates a spectrum of inflammatory cells and induces fever (20). Interleukin 1 (IL-1) and TNF trigger endothelial cells (22) and hepatocytes (23) to release IL-6.

The purpose of the present investigation was to examine the effect of FK 506 in (a) ameliorating the hepatic injury associated with warm ischemia/reperfusion in rats subjected to a $70 \%$ hepatectomy and (b) to determine whether the immunosuppressive and hepatotrophic qualities of FK 506 are due, at least in part, to inhibition of the production and/or release of TNF and IL-6.

\section{Materials and Methods}

\section{Animal model}

By utilizing a rat model of lobar, rather than total hepatic ischemia, a severe ischemic insult can be produced without also inducing mesenteric venous hypertension (24). Utilizing an atraumatic microvascular clamp to interrupt the portal venous and hepatic arterial blood supply to the right lateral lobe of the liver, a 60 min period of total ischemia was produced. With this procedure, the median and left lateral lobes of the liver retain an intact blood flow. Intestinal venous congestion and the possible leakage of bacteria or bacterial products into the circulation is minimized $(25,26)$. Upon releasing the clamp and reperfusion of the right lateral lobe, the median and left lateral lobes of the liver were excised, leaving behind only the previously ischemic right hepatic lobe. All animals used in these studies were adult male Lewis rats (Harlan-Sprague-Dawley, Indianapolis, IN) weighing $200-300 \mathrm{~g}$ which were given free access to standard pellet diet and tap water both before and after the operative procedure. Anesthesia was induced and maintained using metofane inhalation.

\section{Experimental protocols}

Experiment 1. Rats, prepared as described above, were assigned to one of six different experimental groups consisting of 10 rats each. Group 1 animals were injected intravenously with $0.5 \mathrm{ml}$ saline solution and served as the controls. Animals in groups 2-6 were injected intravenously with FK $506(0.3 \mathrm{mg} / \mathrm{kg}$ in $0.5 \mathrm{ml}$ saline $)$ (Fujieawa Corporation, Philadelphia, PA) at 0, 1, 3, 6 or $24 \mathrm{~h}$ prior to the production of the experimental hepatic ischemia. All animals were allowed to recover spontaneously and survival was determined at 12-h intervals for a total of 10 days.

Experiment 2. An additional 110 rats. consisting of five rats in each group prepared identically to those in groups 1 and 5 in Exp. 1, were sacrificed at 24-h intervals beginning immediately after removal of the microvascular clamp at time zero and continuing for the next 10 days. Immediately before being killed, blood was obtained from the intrahepatic inferior vena cava (IVC) of each animal for bioassay of circulating TNF and IL6 concentrations. In addition, blood samples $(0.75 \mathrm{ml})$ were obtained immediately before the $60-\mathrm{min}$ period of ischemia (i.e., $1 \mathrm{~h}$ before the time of reperfusion; $-1 \mathrm{~h}$ ) to determine the pre-ischemic serum concentration of TNF and IL-6. At each blood draw, the blood withdrawn from each animal was replaced by an equal volume of lactated Ringer's solution. The serum was separated immediately and stored at $-20^{\circ} \mathrm{C}$ until being assayed.

\section{TNF bioassay}

The measurement of TNF utilized was based upon quantitation of the cytolytic activity of TNF in lysing L-M (murine mouse connective tissue) cells in the presence of actinomycin $\mathrm{D}$ as measured by the uptake of Crystal violet dye by residual viable cells (Genentech Inc, San Francisco, CA) (27). Briefly, L-M cells were cultivated in serum-free medium (M199 containing $0.5 \%$ Bactopeptone). Confluent monolayers were detached using sterile glass beads, resuspended in M199 supplemented with $0.5 \%$ Bactopeptone, $100 \mathrm{U} / \mathrm{ml}$ penicillin, $100 \mu \mathrm{g} / \mathrm{ml}$ streptomycin, $1 \mu \mathrm{g} / \mathrm{ml}$ insulin and $0.024 \mathrm{M}$ Hepes buffer. The cells were then seeded at a density of $4 \cdot 10^{4}$ cells per well into a 96-well microtiter plate. Following incubation for $22-24 \mathrm{~h}$ at $37^{\circ} \mathrm{C}$ in a humidified atmosphere with $5 \% \mathrm{CO}_{2}$, the medium in the wells was replaced with fresh medium containing actinomycin $D$ at a final concentration of $1 \mu \mathrm{g} / \mathrm{ml}$. The plates are then incubated for an additional $18-20 \mathrm{~h}$ at $37^{\circ} \mathrm{C}$ and stained with $0.5 \%$ Crystal violet, washed, dried and read by a plate reader at $540 \mathrm{~nm}$. Activity levels are reported as units $/ \mathrm{ml}$, where $1 \mathrm{U} / \mathrm{ml}$ equals approx. $8.8 \mathrm{pg} \mathrm{TNF} /$ $\mathrm{ml}$.

\section{IL-6 bioassay}

The levels of IL- 6 in serum were measured utilizing a bioassay system consisting of a hybridoma cell line B9, which was developed in the laboratory of Dr. L.A. Aarden (28). This cell line requires IL-6 for its proliferation and survival in vitro. The cells are maintained in medium consisting of RPMI- 1640 containing $10 \%$ heatinactivated fetal calf serum (HI-FCS), $200 \mu \mathrm{M}$ glutamine, 
$5 \cdot 10^{-5} \mathrm{M} 2 \mathrm{ME}$ (mercaptoethanol), and 20-50 units $/ \mathrm{ml}$ of HGF (hybridoma growth factor). One unit $/ \mathrm{ml}$ of HGF is the concentration of IL- 6 required to achieve $50 \%$ maximal $\left[{ }^{3} \mathrm{H}\right]$ thymidine incorporation $(28.29)$.

The assay $(30.31)$ is carried out as follows: B9 hybridoma cells are washed three times using sterile RPMI1640 containing $1 \%$ HI-FCS. The cells are then resuspended in double strength media (2.RPMI-1640 containing $20 \% \mathrm{HI}-\mathrm{FCS}$ ) at a concentration of $2 \cdot 10^{4} / \mathrm{ml}$. One hundred- $\mu$ l aliquots of the cell suspension were plated into individual wells of a 96-well microtiter plate. One hundred $\mu \mathrm{l}$ of a 2-fold scrial dilution of the serum to be assayed, diluted in RPMI-1640 containing $1 \% \mathrm{HI}$ FCS was added to each of the wells. The plates were then incubated for $84 \mathrm{~h}$ at $37^{\circ} \mathrm{C}$ in a humidified atmosphere with $5 \% \mathrm{CO}_{2}$ and pulsed with $0.5 \mu \mathrm{Ci}$ of $\left[{ }^{3} \mathrm{H}\right]$ thymidine that is incorporated and determined by liquid scintillation counting. The amount of IL-6 (in HGF units) in the scrum sample is defined as the reciprocal of the dilution required to produce $50 \%$ maximum $\left[{ }^{3} \mathrm{H}\right]$ thymidine incorporation by the $B 9$ cell line where $1 \mathrm{HGF}$ unit equals $1 \mathrm{pg} / \mathrm{ml}$ or $5 \cdot 10^{-14} \mathrm{M}$ native IL-6.

In order to determine whether FK 506 itself influenced cither the TNF or IL-6 bioassay, serum and plasma samples taken from rats treated with varying concentrations of FK 506 were utilized in both bioassays. Samples taken from FK 506-treated rats had no detectable effect on either bioassay. Serum and plasma samples were also spiked with TNF (400 units per $\mathrm{ml}$ recombinant human TNF) or IL-6 (12.5 or 25 units per ml recombinant human (L-6). Recovery in all samples was greater than $90 \%$. Thus, FK 506 did not interfere with either bioassay and did not stimulate inhibitors of either TNF or IL-6.

\section{Statistical analysis}

Values are expressed as the mean \pm the standard error of mean. Differences in the means were tested after conversion of the primary data to logarithms using the Student $t$-test. Differences in proportions were evaluated using the Fisher Exact Test: one-tailed significance levels were used for the survival data analysis because the null and alternative hypotheses tested specified the direction of the difference (i.e., proportion of treated animals surviving would be greater than proportion of control animals surviving). A $p$-value of $<0.05$ was considered to be statistically significant.

\section{Results}

\section{Survival rate}

The 10-day survival rate for each of the six groups of animals studied is shown in Fig. 1. All of the group 1 controls died within $72 \mathrm{~h}$ of the ischemic episode. The survival in animals receiving FK $506(0.3 \mathrm{mg} / \mathrm{kg})$ at time 0 (group 2), $1 \mathrm{~h}$ (group 3), and $3 \mathrm{~h}$ (group 4) before the induction of ischemia was increased slightly to $30 \%$, $40 \%$, and $40 \%$, respectively. In contrast, the survival for the group 5 and 6 animals that received the same dose of FK 506 but administered $6 \mathrm{~h}$ (group 5) and $24 \mathrm{~h}$ (group 6) before the initiation of the hepatic ischemia was increased significantly $(p<0.01)$ to $70 \%$ and $80 \%$, respectively. As may be seen also in Fig. 1 , the survival rate remained constant from day 3 post-ischemia through 10 days in all groups of animals studied. Fig. 2 shows a significant positive correlation between the time of FK 506 injection and the percentage of animals surviving at $72 \mathrm{~h}$ after the hepatic ischemia $(r=0.854$, $p<0.05$ ).

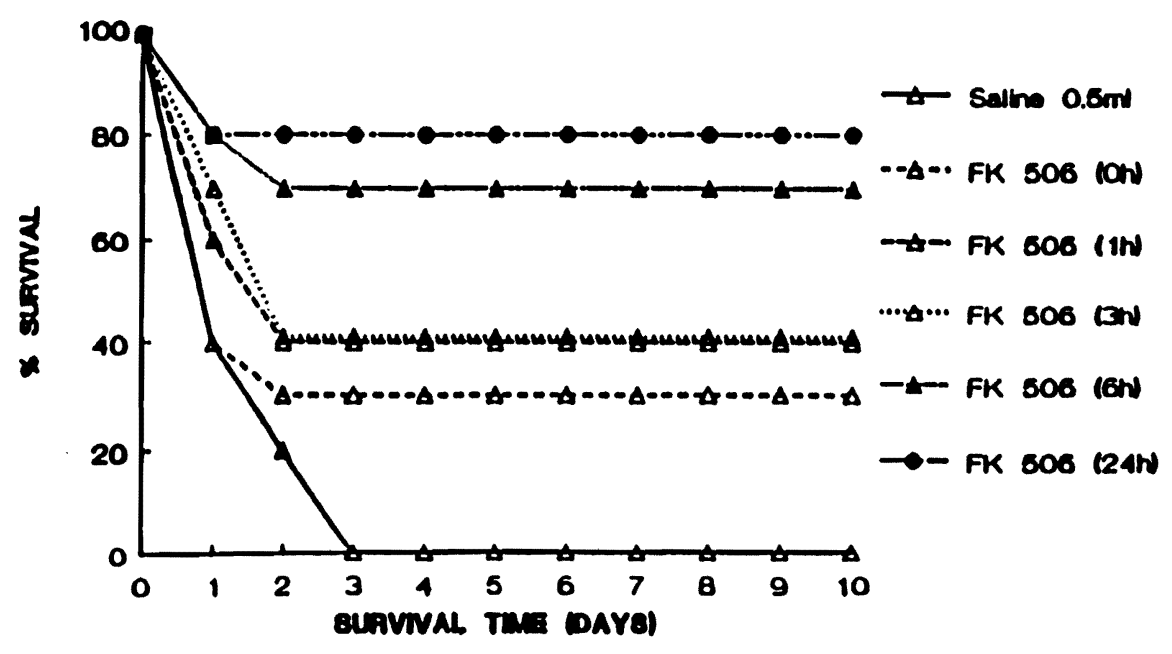

Fig. 1. Survival time-course of the animals studied. 


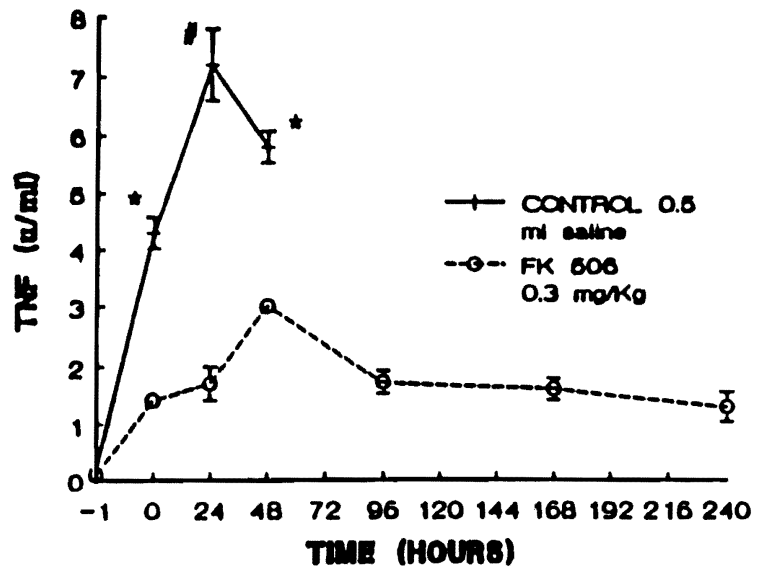

Fig. 2. Serum TNF levels $(U / \mathrm{ml})$ in groups 1 and 5 . The points represent the mean level and the brackets indicate the standard error of the mean ("groups significantly different at $p<0.001$ : \#groups significantly different at $p<0.01$ ). No data are shown for the controls beyond $48 \mathrm{~h}$ because all of the animals had died.

$T N F$ levels following hepatic ischemia/reperfusion

TNF was measurable in the serum of all experimental animals after hepatic ischemia and reperfusion. In contrast, TNF was undetectable in the pre-ischemic samples obtained from the animals in both groups 1 and 5. The mean peak TNF level in the group 1 controls was $7.2 \mathrm{U} /$ $\mathrm{ml}$ with a range of $6.47-8.53 \mathrm{U} / \mathrm{ml}$ and occurred at $24 \mathrm{~h}$ post-ischemia. The mean peak TNF level was $2.99 \mathrm{U} /$ $\mathrm{ml}$ with a range of $2.81-3.06 \mathrm{U} / \mathrm{ml}$ in group 5 animals that received FK $5066 \mathrm{~h}$ before the induction of ischemia and occurred at $48 \mathrm{~h}$ after the ischemic episode (Fig. 3). At each time interval studied. the mean value of TNF was significantly lower in the rats receiving FK 506 (group 5) than it was in the controls $(p<0.01)$.

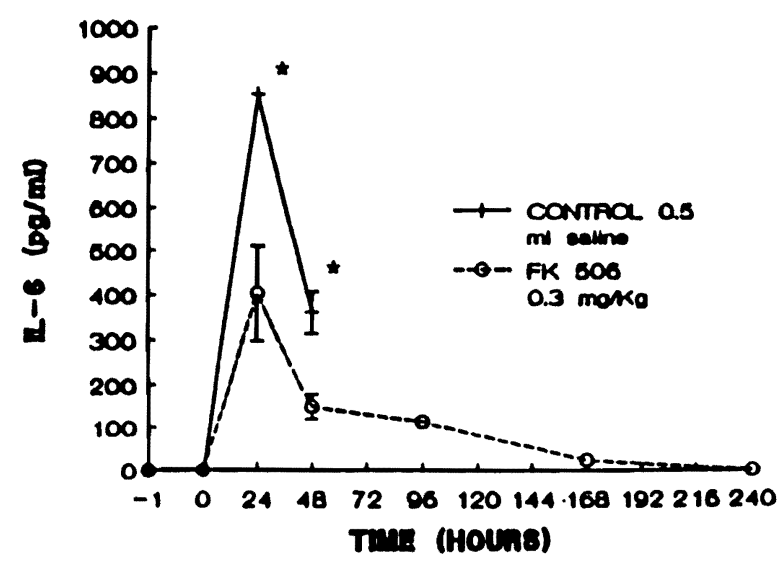

Fig. 3. Serum IL-6 levels $(\mathrm{pg} / \mathrm{ml})$ in groups 1 and 5. The points represent the mean level and the brackets indicate the standard error of the mean ("groups significantly different at $p<0.025$ ). No data are shown for the control animals beyond $48 \mathrm{~h}$ as all animals in this group had died.

\section{IL-6 levels following hepatic ischemia/reperfusion}

The serum IL-6 level in both groups of animals (groups 1 and 5 ) increased after the ischemia/reperfusion and peaked at $24 \mathrm{~h}$. Statistically significant differences were found for the levels in both groups at $24 \mathrm{~h}$ and $48 \mathrm{~h}$ post-ischemia (Fig. 4). The production of IL-6 returned to the pre-ischemic values $(<1 \mathrm{pg} / \mathrm{ml})$ by 10 days post-ischemia.

\section{Discussion}

In the present experimental model, when control rats were subjected to a $70 \%$ hepatectomy involving the median and left lateral lobes of the liver after having sustained a 60 -min period of total ischemia of the unresected right hepatic lobe. they all died within $72 \mathrm{~h}$ (Fig. 1). Survival of such animals is dependent upon the ability of the residual right hepatic lobe to withstand the initial ischemia and subsequent reperfusion injury and to regenerate. Pre-treatment of the animals with a single dose of FK $506(0.3 \mathrm{mg} / \mathrm{kg})$ administered intravenously 6 to $24 \mathrm{~h}$ prior to the induction of the hepatic ischemia (groups 5 and 6 , respectively) was followed by a significant improvement in animal survival $(70 \%$ and $80 \%$, respectively) (Fig. 1).

It is well known that CsA augments hepatic regeneration in rats (7-10) and mice (11) after partial hepatectomy and also in dogs with an Eck-fistula (6). In both models, the effect of an infusion of FK 506 at a much lower dose is similar $(4,5)$. Thus, the recent observation that the events of hepatic regeneration may be modulated immunologically is of considerable interest (32-34). An ischemic injury may be followed by an increased expression of antigens by the injured organ which can initiate an immunologic response that leads to an inflammatory reaction which brings to the injured organ cells that further enhance the liver cell injury. In turn, the immune response becomes more intense (35). Since both CsA and FK 506 are immunosuppressive as well as hepatotrophic, it has been suggested that they might reduce the immune response to the injured graft as well as modulate hepatocyte growth and thereby enhance regeneration (5.36).

However, it is equally possible that the hepatoprotective effect of FK 506 herein observed is independent of its immunosuppressive action (4). The non-immunologic actions of FK 506 appear to be attributed to its interaction with the enzyme cis-trans peptidylprolylisomerase (PPIase). a principal constituent of the cytosolic binding sites of CsA. cyclophilin (37.38) as well as FK 506 binding within cells $(39,40)$. A biochemical mechanism for the beneficial hepatoprotective effect of 
FK 506 is supported by the demonstration, in a similar model, of a faster and more complete restoration of hepatic ATP content, and a reduction in the hepatic necrosis and cytosolic enzyme loss experienced following ischemia/reperfusion (41). Thus, enhanced resistance to hepatic ischemic injury may contribute to the increased survival reported for the FK 506 pretreated animals.

The present data show that a $60-\mathrm{min}$ period of lobar hepatic ischemia followed by reperfusion and $70 \%$ hepatectomy (involving the non-ischemic lobes) results in TNF production (Fig. 3). This finding is consistent with reports from other investigators $(42,43)$. The mechanism of induction of TNF bioactivity seen after hepatic ischemia/reperfusion is not completely olear, however. It appears most likely that the process of ischemia/reperfusion causes immunologically non-specific activation of hepatic macrophages (Kupffer cells) resulting in a release of this cytokine into the systemic circulation. Previous studies in vitro have documented the ability of Kupffer cells to produce TNF (44). Unlike recent reports of a rapid increase in TNF following hepatic infection with murine virus, in the present study the increase in TNF was delayed $24-36 \mathrm{~h} \mathrm{(45).} \mathrm{This} \mathrm{apparent} \mathrm{delay} \mathrm{until} \mathrm{the}$ peak of TNF was noted probably reflects the time required for macrophage activation following ischemia/ reperfusion. Previous studies reported an immediate increase in TNF following viral infection involved pretreatment of the animals for 7 days prior to the injury induced to guarantee an acceleration of activated macrophages within the liver as the source of the TNF (45).

Previous studies have reported that TNF not only has a deleterious effect on hepatocytes but also has damaging pulmonary effects resulting in pulmonary neutrophil sequestration and hemorrhagic edema $(42,43)$. This observation may be of clinical importance especially in the field of transplantation as primary non-function of the graft is associated frequently with the rapid development of pulmonary insufficiency (46).

The mechanisms by which TNF produces pulmonary and hepatic as well as other organ injury have not yet been clarified. However, TNF has been demonstrated to induce the expression of endothelial cell adherence proteins which are responsible for binding neutrophils and monocytes $(47,48)$. TNF also has been shown to activate neutrophils, increase phagocytic activity and cause their degranulation, as well as acting as a chemoattractant $(45,50)$. It causes neutrophils to produce superoxide anions, hydrogen peroxide and other toxic metabolites $(48,51)$. It also induces endothelial cells to produce a variety of cytokines (52-56). Thus, the vascular injury that follows hepatic ischemia/reperfusion may occur as a consequence of the action of TNF on endothelial cells and neutrophils. Alternatively, it is possible that the high levels of plasma IL- 6 reflect the severity of the biological mechanisms involved in rescuing the injured liver. This latter hypothesis is unlikely, however, as the utilization of monoclonal antibodies to IL- 6 does not impair regeneration but does reduce tissue injury following a variety of tissue insults (15-17).

In the present experiments (Exp. 2), a single intravenous dose of FK $506(0.3 \mathrm{mg} / \mathrm{kg})$ administered $6 \mathrm{~h}$ prior to the induction of ischemia significantly inhibited TNF production (Fig. 3). While the precise mode of inhibition of TNF activity by FK 506 remains unknown, one explanation may be that FK 506 has a direct effect on macrophages or on the communication between macrophages and T lymphocytes. Since both cells are required for T-cell activation (IL-2 production), the identity of the particular cell lines affected by FK 506 is an important issue that merits further evaluation.

In the present study, lobar hepatic ischemia/reperfusion injury resulted in the production of IL- 6 with IL-6 levels peaking at $24 \mathrm{~h}$ post-ischemia. Significant inhibition of IL-6 production occurred following the administration of FK 506 (group 5) (Fig. 4). Moreover, the use of FK 5066 to $24 \mathrm{~h}$ prior to the hepatic ischemia dramatically improved survival.

IL- 6 is produced by a wide variety of cells including monocytes/macrophages, endothelial cells as well as $T$ and B lymphocytes. Inducers of IL- 6 production include IL-1 and TNF, suggesting that the effect of IL-1 and TNF as part of the acute phase response could be mediated, at least in part, by IL-6 (56). Because IL-6 has a broad spectrum of target cells. it influences a broad array of immune and inflammatory responses in vitro and possibly also in vivo (20).

The stimulation of T-cell proliferation by IL- 6 involves not only a direct growth-promoting signal, but also the induction of IL-2 receptors. This latter event converts T-cells to an IL-2-responsive state (20). B-cell growth and differentiation to antibody-secreting cells is enhanced by IL- 6 in the presence of the appropriate stimuli $(58,59)$. The hepatocyte is yet another major target of IL-6 (57). IL-6 exhibits a synergistic effect with IL-1 on the induction of acute-phase protein production by hepatocytes. An inhibition of IL-6 release by FK 506 pre-treatment may be one of the mechanisms behind the observed hepatoprotective action of FK 506.

In conclusion, our data showed that FK 506 pretreatment attenuates the hepatic injury resulting from ischemia/reperfusion manifested as an improvement in survival. Hepatic ischemia/reperfusion injury triggers the 
release of TNF and IL-6. FK 506 inhibits the production/ release of these two cytokines. These findings contribute to an understanding of the full spectrum of immunosuppressive and hepatoprotective effects of FK 506.

\section{References}

I Makowka L. Gordon RD. Todo S, et al. Analysis of donor criteria for the prediction of outcome in clinical liver transplantation. Transplant Proc 1987: 19: 2378.

2 Shaw BW Jr, Gordon RD. Iwatsuki S, Starzl TE. Hepatic retransplantation. Transplant Proc 1985; 17: 264.

3 Starzl TE. Todo S. Fung J, Demetris AJ, Venkataramanan R, Jain A. FK 506 for human liver, kidney and pancreas transplantation. Lancet 1989; ii: 1000-4.

4 Starzl TE. Porter KA. Mazzaferro V. et al. Hepatotrophic effects of FK 506 in dogs. Transplantation 1992: in press.

5 Francavilla A. Barone M, Todo S. Zeng Q, Porter KA, Starzl TE. Augmentation of rat liver regeneration with FK 506 compared with cyclosporine. Lancet 1989; ii: 1248-9.

6 Mazzaferro V. Porter KA. Scotti-Fogliene CL. et al. The hepatotrophic influence of cyclosporine. Surgery 1990; 107: 533-9.

7 Kim YI, Salvini P. Auxilia F, Calne RY. Effect of cyciosporine A on hepatocyte proliferation after hepatectomy in rats: comparison with standard immunosuppressive agents. Am J Surg 1988; 155: 245.

8 Makowka L. Svanas G, Esquivel C. et al. The effect of cyclosporine on hepatic regeneration. Surg Forum 1986; 37: 352-4.

9 Kahn D, Lai HS. Romovacek H, Makowka L, Van Thiel DH, Starzl TE. Cyclosporin A augments the regeneration response after partial hepatectomy in the rat. Transplant Proc 1988: 20: 850-2.

$10 \mathrm{Kim}$ YI, Calne RY. Nagasue N. Cyclosporin A stimulates proliferation of the liver cells after partial hepatectomy in rats. Surg Gynecol Obstet 1988; 166: 317-22.

11 Yushimira S, Kamada N. Effect of cyclosporin A on liver regeneration following partial hepatectomy in the mouse. Transplant Proc 1989; 21: 911-2

12 Kahan BD. Cyclosporine. N Engl J Med 1989; 321: 1725-38.

13 Kino T, Hatanaka H, Miyata S, et al. FK 506, a novel immunosuppressant isolated from a streptomyces. Il. Immunosuppressive effect of FK 506 in vitro. J Antibiotics 1987: 40: 1256-65

14 Pennica D. Nedwin GE, Hayflick JS, et al. Human tumor necrosis factor: precursor structure, expression and homology to lympho. toxin. Nature 1984; 312: 724-9.

15 Hishinuma I. Nagakawa J, Hirota K. et al. Tumor necrosis factor$\alpha$ in galactosamine-induced hepatitis. Hepatology 1990; 12: 1187-91.

16 Honchel R, Marsano L, Cohen D, Shedlofsky S, McClain CJ. Lead enhances lipopolysaccharide and tumor necrosis factor liver injury. J Lab Clin Med 1991: 117: 202-8.

17 Nagakawa J, Hishinuma I, Hirota K. et al. Involvement of tumor necrosis factor $\alpha$ in the pathogenesis of activated macrophagemediated hepatitis. Gastroenterology 1990; 99: 758-65.

18 Maury CJ, Teppo AM. Raised serum levels of cachectin/tumor necrosis factor in renal allograft rejection. J Exp Med 1987: 166 $1132-7$.

19 Chollet-Martin S. Depoix JP, Hvass U, Pansard Y, Vissuzaine C Gougerot-Pocidalo MA. Raised plasma levels of tumor necrosis factor in heart allograft rejection. Transplant Proc 1990; 22: 2836.

20 Kishimoto T. The biology of interleukin-6. Blood 1989; 74: 1-10.

21 Mizel SB. The interleukins. FASEB J 1989; 3: 2379-88.

22 Jirik FR, Podor TJ. Hirano T, et al. Bacterial lipopolysaccharide and inflammatory mediators augment IL- 6 secretion by human endothelial cells. J Immunol 1989: 142: 144-7.

\section{Acknowledgement}

This work was supported in part by grants from the NIDDK 39789 and NIDDK 32556.

23 Lotz M, Zuraw BL. Carson DA. Jirik FR. Hepatocytes produce interleukin-6. Ann NY Acad Sci 1989; 557: 509-11.

24 Hayashi H. Chaudry IH. Clemens MG. Baue AE. Hepatic ischemia models for determining the effects of ATP- $\mathrm{MgCl}_{2}$ treatment. J Surg Res 1986: 40: 167-75.

25 Meer C, Kley GA. Valkenburgh PW. Studies on the cause of death after permanent and temporary occlusion of the portal vein in rats. Circ Shock 1976; 3: 191.

26 Farber JL, Chien KR, Mittnacht Jr S. Myocardial ischemia: the pathogenesis of irreversible cell injury in ischemia. Am J Pathol 1981; 102: 271-81.

27 Kramer SM. Carver ME. Serum-free in vitro bioassay for the detection of tumor necrosis factor. J Immunol Methods 1986: 93: 201-6.

28 Aarden LA. DeGroot ER. Schaap OL. Landsdrop PJ. Production of hybridoma growth factor by human monocytes. Eur J Immunol 1987: 17: 1411-6.

29 Van Snick J, Cayphas A, Vink 'A, et al. Purification and $\mathrm{NH}_{2}-$ terminal amino acid sequence of a T-cell derived lymphokine with growth factor activity for B-cell hybridomas. Proc Natl Acad Sci USA 1986: 83: 9679.

30 Nordan RP, Potter M. A macrophage-derived factor required by plasmacytomas for survival and proliferation in vitro. Science 1986; 233: 566-9.

31 Nordan RP. Pumphrey JG, Rudikoff S. Purification and $\mathrm{NH}_{2}$ terminal sequence of a plasmacytoma growth factor derived from murine macrophage cell line P388DI. J Immunol 1987; 139: 8137.

32 Miyahara S. Yokomuro K. Takahashi H, Kimura Y. Regeneration and the immune system, $\mathrm{I}$ : in vitro and in vivo activation of lymphocytes by liver regeneration and the role of Kupffer cells in stimulation. Eur J Immunol 1983; 13: 878-83.

33 Sakai A. Pfeffermann R. Kountz SL. Liver regeneration and lymphocyte activation. Surg Gynecol Obstet 1976: 143: 914-8.

34 Perez-Tamayo R, Romero R. Role of the spleen in regeneration of the liver: an experimental study. Spleen/Liver Regeneration 1958: 7: 248-57.

35 Howard TK, Klintmalm GBG, Cofer JB, Husberg BS. Goldstein $\mathrm{RM}$, Gonwa TA. The influence of preservation injury on rejection in the hepatic transplant recipient. Transplantation 1990; 49: 1037

36 Francavilla A. Barone M. Starzl TE, et al. FK 506 as a growth factor. Transplant Proc 1990; 22: 90-2.

37 Takahashi N, Hayano T. Suzuki M. Peptidyl-prolyl cis-trans isomerase is the cyclosporin A-binding protein cyclophilin. Nature 1989: 337: 473-5.

38 Fischer G. Wittmann-Liebold B. Lang K. Kiefhaber T, Schmid FX. Cyclophilin and peptidyl-prolyl cis-trans isomerase are probably identical proteins. Nature 1989: 337: 476-8.

39 Siekierka JJ. Hung SHY, Poe M. Lin CS, Sigal NH. A cytosolic binding protein for the immunosuppressant FK 506 has peptidylprolyl isomerase activity but is distinct from cyclophilin. Nature 1989; 341: 755-7.

40 Harding MW. Galat A. Uehling DE. Schrieber SL. A receptor for the immunosuppressant FK 506 in a cis-trans isomerase. Biochim Biophys Acta 1984; 828: 39-42.

41 Sakr MF. Zetti GM. Farghali H. et al. Protective effect of FK 506 against hepatic ischemia in rats. Transplant Proc 1991: 23: 340-1 42 Colletti LM, Remick DG. Burtch GD, Kunkei SL, Strieter RM. 
Campbell Jr DA. Role of tumor necrous tectorsalpha in the pathophysiologic alteration after hepalik uschemia/reperfusion injury in the rat. J (lin Invest 1990. 85: 19.4.

43 Colletti L.M. Burtch GD. Remick DG. el al. The production of tumor necrow, lictior alpha and the development of a pulmonary capillary injur following hepatic ischemia/reperfusion. Transplantation 1990): 49: 268-72.

44 Magilavy DB. Kothstein JL. Spontanecous production of tumor necrosis factor alpha by kupfier cells of MRL I pr mice. J I:xp Med 1988: 168: 789-94

45 Nagakawal J. Hishınuma I. Hirota K. et al. Involvement of tumor necrosis factors in the pathogenexis of activated macrophage mediated hepatitis in mice. Gusiroenterology (94): $94: 75 \%-65$.

46 Matuschak GM. Rinaldo Jl: Pinsky MR. Gavaler JS. Van Thicl DH. Effect of end stage liver faslure on the incidence and resolution of the adult respiratory distress syndrome. J Crit ('ure 1987: 2: 162-73.

47 Gamble JR. Harlan JM. Klchanoff SJ. Vadas MA. Stimulution of the adherence of neutrophils to umbilical vein endothelium by human tumor necrosis factor. Proc Natl Acad Sci USA 1985: 82: 8667.

48 Pohlman TH. Stanness KA. Beatty PG, Ochs HD. Harlan JM. An endothelial cell surface factor(s) induced in vitro by lipopolysac. charide. interleukin-1. and tumor necrosis factor alpha increases neutrophil adherence by a CDW18-dependent mechanism. J Immunol 1986: 136: 4548-53.

49 Wankowicz Z. Megyeri P. Issekutz A. Synergy between tumor necrosis factor alpha and interleukin- $l$ in the induction of polymorphonuclear leukocyte migration during inflammation. J Lcuk Biol 1988: 43: 349.

50 Ferrante A. Nandoskar M, Walz A. Goh AH, Kowano 1. Effects of tumor necrosis factor alpha and interleukin-1 alpha and beta on human neutrophil migration. respiratory burst and degranulation. Int Arch Allergy Appl 1988: 86: 82.
S) Shalaby MR. Aggarwal BB. Rinderknecht E. Svedersky LP. Finkle BS. Palladino MA. Activation of human polymorphonuclear neutrophil functions by intericron-gamma and tumor necrosis factors. J Immunol 1985: 135: 2069-73.

S2 Nawroth PP. Bank I. Hadley D. Cassımeris J. Chess L. Stern D. Tumor necrosis factoricachectin interacts with endothelial cell receptors to induce release of interleukin-I. J Exp Med 1987: 163: 1363-75

\$3 Hanjar KA. Hallar DP. Silverstein RL. Nackman RL. Tumor necrosis factor-mediated release of platelet-derived growth factor from culture endothelial cells. J Exp Med 1987: 16: 235-45.

$\$ 4$ Camussi G. Bussolino F. Salvidio G. Baglioni C. Tumor necrosis factor/cachectun stimulates peritoneal macrophages. polymorphonuclear leukocytes and vascular endothelial cells to synthesize and release platelet-activating factor. J Exp Med 1987: 166: 1390-4.

ș Kuwakani M. Ishibashi S. Ogawa H. Murosc T. Takaku F. Shibata $S$. (achectin/TNF as well as interlcukin-I induces prostacyclin synthesis in cultured vascular endothelial cells. Biochem Biophys Res Commun 1986: 141: 482-7.

Sh Strieter RM. Kunkel SI. Showell HJ. et al. Endothelial cell gene expression of a neutrophil chemotactic factor by TNF-alpha. LPS and II. 1 beta. Science 1988: 24.3: 1467-9.

57 Gauldic J. Richards (: Marnish D), Landsdrop P. Baumann H. Interferon-B, $\mathbf{B}_{2} \mathbf{B}$-cell stumulatory lactor type 2 shares identity with monocyle-derived hepatocyle-stimulating factor and regulates the major acute phase protein response in liver cells. Proc Natl Acad Sci USA 1987: 84: 7251-5.

58 Billiau A. Van Damme J. Ceuppens J. Baroja M. Interleukin 6. a ubiquitous cytokine with paracrine as well as endocrine functions. In: Fradelizi D. Bertoglio J. eds. Lymphokine Receptor Interactions. London: John Libby Furotext Lid.. 1989; 133-42.

59 Kishimoto T. Hirano T. Molecular regulation of B lymphocyte response. Annu Rev Immunol 1988: 6: 485-512. 